\title{
The Impact of Interplay between Formal and Informal Institutions on Innovation Performance: Evidence from CEECs
}

\author{
Malgorzata Godlewska
}

\author{
SGH Warsaw School of Economics, \\ Niepodleglosci 162 St., 02-554 Warsaw, Poland \\ E-mail.mgodlews@sgh.waw.pl
}

cross $^{\text {ref }}$ http://dx.doi.org/10.5755/j01.ee.32.1.27390

\begin{abstract}
Formal and informal institutions matter in the context of the innovation performance of Central and Eastern European countries (CEECs). The purpose of the research was to investigate whether the interplay between formal and informal institutions has a positive, negative or neutral impact on the innovation performance of CEECs, and if formal or informal institutions alone also have a positive, negative or neutral influence on the innovation performance of CEECs. The research is based on informal institutions of CEECs such as trust, traditions, customs, creativity or cooperation, and formal institutions of CEECs such as law, formal rules, or science, technology and innovation policy (STIP). The research methodology focuses on secondary statistical data from 18,808 surveys from the European Social Survey Round 9 (2018) edition 2.0 for informal institutions and from 1090 innovation policies of European Commission and OECD STIP Compass and 414,073 notices of awarded tenders of the European Union Tenders Electronic Daily for formal institutions. Innovation performance was measured by the Summary Innovation Index (SII) of the European Innovation Scoreboard 2019. The findings show that informal institutions such as trust in others, trust in the legal system, the importance of following traditions and customs or cooperation among citizens of CEECs, as well as interplay between informal institutions such as trust in the legal system and formal institutions such as obedience to rules among citizens of CEECs have a negative impact on the innovation performance of the national economies of CEECs. Meanwhile, the variety of policy theme areas and creativity among citizens of CEECs have a positive impact on the innovation performance of the national economies of CEECs.
\end{abstract}

Keywords: Innovation; Formal Institutions; Informal Institutions; Innovation Performance; CEECs; Culture; Regulations.

\section{Introduction}

Nowadays, innovation is perceived as one of the key factors for each national economy (Romer, 1990; Edquist, 2005; Tidd, 2006) and a crucial condition for sustainable growth in Europe (European Commission, 2016).

However, no common definition of innovation has been presented in the literature on the subject. For some authors such as Granieri \& Renda (2012) or Edquist (2005), innovation means progress derived from the creation of new resources of economic importance. For other authors such as Phelps (2013) or Denning and Dunham (2010), it is not the innovation per se, which is crucial, but its practical successful implementation or business commercialisation. Problems with the definition of innovation results from the complicated nature of these phenomena and the novelty of the topic, which has a huge impact on assessing the problem. Hence, no one common measure of the innovation performance of national economies prevails in the literature.

Innovations depend on economic factors, factors specific to an enterprise, and legal factors such as regulations or tax rules (OECD Oslo Manual, 2005). Regulations (formal institutions) may enable and/or hinder innovation in Central and Eastern European countries ${ }^{1}$ (CEECs) and may enhance and/or reduce incentives to innovate (Pelkmans \& Renda,

${ }^{1}$ Central and Eastern European Countries (CEECs) is an OECD term for the group of countries comprising Albania (as a non-UE member excluded from analysis), Bulgaria, Croatia, the Czech Republic,
2014). On the other hand, institutions can provide stable conditions for innovative efforts (Lundvall, 1992).

It is not only formal institutions (such as public procurement law, innovation law, tax law or intellectual property law) which matter in terms of innovation. A marked impact also derives from informal institutions (for example, culture, values or norms). Phelps (2013) highlights the fact that informal institutions stimulate the innovation process and performance. Informal institutions such as creative culture, entrepreneurship culture, learning culture, productive culture or values and norms such as trust, cooperation, reciprocity or a positive attitude to risk are necessary ingredients for innovation performance (Cooke et al., 1997; Hofstede, 1980, 2001; Lundvall, 2007; Chen et al., 2008). Moreover, only interplay between informal and formal institutions may generate synergy effects (Shane, 1993) in the form of improvement in the level of innovation performance of CEECs.

CEECs, in their modern history, were never technology or innovation leaders (Berend, 2009). However, among CEECs we can distinguish strong innovators such as Estonia, moderate innovators such as Lithuania, Czechia, Slovenia, Hungary or Poland and modest innovators such as Bulgaria and Romania (European Commission, 2019a). There may be many explanations for the divergence in innovation performance among CEECs which have a common 
communist past. However, according to Edquist and Zabala (2012), this divergence in innovation performance among CEECs is caused by the set of institutions.

Researchers have until now focused on: i) the regional innovation process (Rodriguez, 2014); ii) the innovation capacity of small and medium-sized enterprises (SMEs) (Dukic et al., 2015) or industrial structure in innovation capacity (Zdrazil et al., 2016); iii) the innovation ecosystem (Jucevicius et al., 2016); iv) open innovation policies (Sekliuckiene et al., 2016); v) the innovation environment and innovation activities of strong, moderate or modest innovators among CEECs (Prokop \& Stejskal, 2017); vi) innovative SMEs (Belas et al., 2017); vii) pro-innovation factors (Kraftova \& Kraft, 2018); viii) the impact of human resources, research networks, the institutional environment, public or private expenditures on research and development (European Commission, 2019a); or ix) measuring the innovation performance of developed and developing regions (Ghazinoory et al., 2014). Others focused on confirming the impact of formal or informal institutions on innovation performance in various countries. Pelkmans \& Renda (2014) verified the interaction between European Union (EU) formal institutions (regulations) and innovation. Hofstede (1980, 2001) and his followers - for example, Shane (1993), Williams \& McGuire (2010) or Bergiel et al. (2012) concentrated specifically on selected dimensions of culture and their influence on innovation performance. Hitherto, common literature has not covered the interplay between formal institutions (such as law or implemented and repeated science, technology and innovation (STI) policy) and informal institutions (such as trust, creativity, traditions, customs, rules and cooperation) and their effect on innovation performance, especially that of CEECs.

Moreover, the CEECs were chosen deliberately, because countries like Poland have innovation gaps between regions (Czudec et al., 2019), and these gaps may be diminished in future thanks to the interplay between formal and informal institutions.

The main research objective was to investigate whether the interplay between formal and informal institutions has a positive, negative or neutral impact on the innovation performance of CEECs, and if formal or informal institutions alone also have a positive, negative or neutral influence on the innovation performance of CEECs.

Here, the secondary statistical data of 18,808 surveys of European Social Survey (ESS) Round 9 (2018) edition 2.0 (except Romania) for informal institutions, and 1090 innovation policies of STIP Compass analysis (2018) and 414,073 record notices of tenders awarded in the European Union Tender Electronic Daily (2018) for formal institutions, were used to assess the impact and significance of interplay between formal and informal institutions on the level of innovation performance of CEECs. Innovation performance was measured by means of the Summary Innovation Index (SII) of the European Innovation Scoreboard (European Commission, 2019a).

The structure of this study is as follows: the initial part focuses on the scientific problem, novelty, aim and research methods. The second section presents the most significant research studies on the impact of formal and informal institutions on innovation performance. The third section discusses the applied research methodology, including a conceptual model of the relationship between institutions (formal and informal) and innovation performance. The fourth section presents the research results. The fifth section focuses on discussion. The final section concludes the main findings and references.

The paper's contribution is threefold: i) it attempts to combine the relationship between formal and informal institutions of CEECs and innovation performance in one conceptual model; ii) it shows that only the variety of policy theme areas and creativity among citizens of CEECs have a positive impact on the innovation performance of CEEC economies. Meanwhile, trust in others, trust in the legal system, the importance of following traditions and customs or cooperation among citizens of CEECs, as well as interplay between informal institutions such as trust in the legal system and formal institutions such as obedience in following rules among citizens of CEECs have a negative impact on the innovation performance of CEEC economies; and iii) it reveals that CEECs such as Bulgaria, Romania or Poland, which have lower levels of cooperation, trust in the legal system or trust in others and pay much greater attention to following traditions and customs or rules than Estonia, Czechia or Lithuania, have a lower innovation performance.

\section{Literature and Hypotheses Development}

Innovations, according to new growth theory (Romer), new economic geography (Krugman) or new economics of innovation (Nelson), are key factors in each national economy (Acs \& Varga, 2002). However, transition countries such as Poland, Hungary, Romania or Bulgaria have innovation gaps between regions (Czudec et al., 2019) and require strong institutions in order to close these gaps.

Moreover, as argued by Williams \& McGuire (2010), innovations generate national prosperity. In addition, thanks to strong support from formal and informal institutions, innovation activities may also have a positive impact on innovation performance, since innovations are uncertain and often conflict-ridden (Edquist \& Johnson, 2005).

Furthermore, Shane (1993) argues that rising expenditures on research and development by public organisations are not sufficient to improve innovation performance if informal institutions are weak or lacking. That is why, especially in the present turbulent time connected with COVID-19, CEECs should support changes to their informal institutions in order to stimulate innovation performance, instead of simply spending money on research and development. Zhao et al. (2020) add that governments of countries with weak informal institutions such as entrepreneurs with a negative attitude to risk should establish a risk guarantee mechanism such as an innovation insurance fund in order to promote the innovation process which may influence high innovation performance later.

High innovation performance among CEEC economies may support their competitiveness on global markets, which is critical in the present situation associated with decreasing gross domestic products, shrinking markets, diminishing customer demand and growing pressure for lower prices.

Edquist and Zabala (2012) argue that innovation performance depends on a set of institutions, which may be understood as "the rules of the game in society or, more formally, are the humanly devised constraints that shape 
human interaction. In consequence, they structure incentives in human exchange, whether political, social, or economic" (North, 1990, p. 3).

According to North (1990), institutions that support innovation may be divided by the rule component, into: i) formal institutions such as: formal rules and norms like national innovation systems; laws such as innovation law, property rights law, public procurement law, tax law or bankruptcy law and constitution; ii) informal institutions such as: creative culture, learning culture, productive culture or innovative culture, customs, conventions, norms and values, such as trust, reciprocity, cooperation and positive attitude to risk; and iii) enforcement characteristics such as sanctions for breaking the rules. However, not all scholars agree on such a division of institutions.

\section{Informal Institutions}

Informal institutions such as culture, customs, traditions or cooperation are necessary for initiating the innovation process, as Shane (1993) proved based on research on national rates of innovation in 33 countries in 1975 and 1980. However, that study did not cover any CEECs which, due to their common communist past, differ from countries such as the United States, the United Kingdom, Japan or France. Moreover, based on the literature review, Herbig \& Dunphy (1998, p. 15) emphasise the huge impact of culture on innovation capacity, in contrast to traditional, conservative values, which put the state over the individual and diminish the flow of new ideas and innovation. Furthermore, the high innovation capacity of a country may later have a positive impact on the higher innovation performance of that country. Phelps (2013) also underlines the significant role of culture, which may inspire individuality, creativity or imagination necessary for innovation. In addition, based on Hofstede's variables and data from 63 countries, Williams \& McGuire (2010), argue that culture affects innovation and national prosperity. However, based on the literature review, Westwood \& Low (2003) argue that culture can and does impact the innovation process, but this relationship is neither universal nor simplistic. Others such as Mir-Babayev et al. (2017), based on research on Azerbaijan construction firms, or Shahzad et al. (2017), based on research into 215 Pakistan software companies, highlight that culture matters in terms of the innovation performance of these companies. The better innovation performance of these companies may subsequently have an impact on the better innovation performance of Azerbaijan or Pakistan as countries.

Informal institutions such as creativity or a positive attitude to risk are important in the innovation process, as Mokyr (1991) proved based on the history of technological progress and by tracing the major inventions and innovations that have transformed our societies. Creativity is an important "part of the innovation process" (Westwood \& Low, 2003, p. 236). In addition, based on the tracing of nations' prosperity between 1820 and 1960, Phelps (2013) argues that creativity or insight may support innovation activity; however, these factors form only a starting point for the innovation process and are not sufficient conditions alone. Innovation also requires strong property protection, economic and legal freedom or democracy (Phelps, 2013).
Informal institutions such as trust, respect for others and confidence in individual self-determination encourage social interaction or reduce transaction costs, and thus may influence innovation performance as a result, as Tabellini (2010) proved based on research into 69 regions in eight European countries such as France, Germany (except East Germany and Berlin), the United Kingdom, Italy, the Netherlands, Belgium, Spain and Portugal. Moreover, based on research on 11 Eurozone countries - namely Austria, Belgium, Finland, France, Germany, Greece, Ireland, Italy, the Netherlands, Portugal and Spain - from 1999 to 2013, Bonasia et al. (2016) highlight the fact that trust in European institutions such as the European Central Bank, the European Commission or the European Parliament play a significant role in economic, political or social stability, which are key factors in high innovation performance.

However, the abovementioned research results did not focus on the impact of informal institutions on the innovation performance of CEECs.

Therefore, in this paper, the following hypothesis was introduced in order to examine the impact of informal institutions on the innovation performance of CEECs:

H1: The higher the level of trust, creativity, cooperation, and drive to follow traditions and customs among citizens of CEECs, the higher the level of innovation performance of CEEC economies.

\section{Formal Institutions}

Formal institutions play a significant role in increasing the innovation performance of CEECs, because they correct market failures which might have occurred due to external costs or asymmetric information (Pelkmans \& Renda, 2014).

In the past two decades, the European Union (EU) has attempted to prevent the innovation performance gap among member states widening further by standardising innovation regulations and policies. Examples of such actions are the Lisbon strategy, the Single Market Strategy, the European Research Area, the Innovation Union, the Better Regulation Agenda, the Research Infrastructure Roadmap and the Smart Specialisation Strategy. However, according to the European Commission (EC) (2014, p. 14), "inconsistencies of rules and practices remain and are hampering the development of high growth innovative firms".

Based on analyses of existing institutions and payment infrastructure, Chiu (2017) argues that formal institutions such as consumer protection regulations are essential for the further development of payment innovations like Bitcoin or autonomous organisation technologies, because only formal institutions may limit the disruptive impact of payment innovations. This may also be the case in the context of innovation performance.

Pelkmans \& Renda (2014, p. 5), based on case studies of European Union regulations (formal institutions), argue that innovation law or public procurement law "matter at all stages of the innovation process" and are "a powerful stimulus to innovation". However, Y. Qu et al. (2017), based on data from the World Bank Enterprise Survey 2012 on Chinese firms, highlight that formal institutions, such as innovation law or property rights protection regulations, had no influence on the promotion of innovation in Chinese firms. Meanwhile, Cheng et al. (2020), based on research into 164 
Chinese agricultural enterprises from 2009 to 2017, underline the fact that the stronger the formal system and institutions, the better the innovation performance of agricultural enterprises. In addition, Ashford (2000), based on theoretical approaches towards environment regulations and innovations or international case studies, emphasises that weak or inappropriate formal institutions may affect entrepreneurs' willingness, opportunity or capability to change and subsequently to innovate, and therefore have a negative impact on innovation performance. For this reason, formal institutions may have a huge impact on innovation performance. However, the above mentioned research results are inconclusive and did not focus on the influence of formal institutions on the innovation performance of CEECs.

Formal institutions may influence the innovation performance of CEECs by means of i) entry regulations, which may be connected with higher levels of corruption and a larger unofficial economy, as entry regulations benefit politicians and bureaucrats, not innovators (Djankov et al., 2002); ii) intellectual property protection, which affects strategic entrepreneurial behaviour towards or against innovation (Autio \& Acs, 2010); iii) tax policy, which may stimulate research and development (Tassey, 2007); iv) antitrust rules (Jorde \& Teece, 1990), which may hamper or support cooperation between competitors or the establishment of innovation networks; and v) a selfenforcement mechanism for ensuring rules are followed (Godlewska, 2019), which may undermine innovation performance due to the fact that innovation requires freedom for Schumpeterian destruction.

Moreover, based on their theoretical concept of institution, Edquitst \& Johnson (2005) argue that innovation policies which are repeated over time evolve into formal institutions, such as formal arrangements (rules) which are taken for granted. According to Pelkmans \& Renda (2014), innovation policies affect innovation incentives, and are thus important for innovation performance.

Therefore, in this paper, the following hypothesis was introduced in order to examine the impact of formal institutions on the innovation performance of CEECs:

H2: The greater the variety of policy instruments and theme areas and the more innovative the public procurement law (measured by tenders with innovative evaluation criteria), the higher the level of the innovation performance of CEEC economies.

\section{Interplay between Formal and Informal Institutions}

Informal institutions, according to Helmke \& Levitsky (2004) or Grzymala-Busse (2010), may replace, undermine, support or compete with formal institutions. On the other hand, according to Pejovich (1999), formal institutions may suppress, conflict, ignore or "cooperate" with informal rules. For high innovation performance of CEECs, formal institutions should "cooperate" with informal ones.

Moreover, based on a cross-section sample of 62 countries, Lee \& Law (2017) underline that countries with higher formal institutions (understood as institutional quality) and higher informal institutions (understood as social capital) are associated with higher innovation levels as measured by a patent application. By contrast, Wang et al. (2019), based on data from 234 technology-based entrepreneurial firms listed on the Chinese Growth Enterprise Market, argue that formal institutions (understood as marketisation) positively affect the relationship between network centrality and innovation performance, whereas informal institutions (understood as social cohesion) have a negative impact. However, these results are inconclusive and did not focus on the influence of interplay between formal and informal institutions on the innovation performance of CEECs.

Therefore, in this paper, the following hypothesis was introduced in order to examine the impact of interplay between formal and informal institutions on the innovation performance of CEECs:

H3: The higher the level of trust in the legal system and obedience to rules among citizens of CEECs, the higher the level of innovation performance of CEEC economies.

\section{Methodology}

The methodology of the study involved a four-stage approach: i) identification of institutional variables that may influence the innovation performance of CEECs; ii) investigation of the correlations between identified variables; iii) testing the assumption of normal distribution; and iv) employing a non-parametric test for unpaired observations. This study uses methods and variables connected with the aim of the research and with regard to the proposed concept of the relationship between formal and informal institutions and innovation performance. Moreover, Ghazinoory et al. (2014) highlight the fact that the method and the selection of the proxy variables are influenced by the researcher's approach to the definition of the concept of innovation or innovation performance.

The research focuses on the effects of interplay between formal and informal institutional variables on the innovation performance of CEECs. However, Smith (2005, p. 149) argued that, due to multidimensional novelty, innovations are "difficult to measure or intrinsically non-measurable". Despite that, "innovation performance", according to Smith (2005), may be captured by input and output (outcome) indicators.

The most popular indicators of innovation performance are: i) expenditures on R\&D such as BERD (business expenditure on research and development) or GERD (government expenditure on research and development); ii) number of patent applications; iii) number of research grants; iv) new product announcements; v) scientific publications and citations; vi) sales impact of new or changed products; or vii) technological collaboration (Hagedoorn \& Cloodt, 2003; Oslo Manual, 2005; Smith 2005; Birchall et al., 2011; Hsu et al., 2015; Lee \& Law, 2017). However, not all scholars accept these indicators.

Other scholars, such as Hollanders \& van Cruysen (2008), Sitanyi (2010) or Adam (2014), recommend the use of the European Innovation Scoreboard (EIS) ${ }^{2}$ based on the most recent statistics from Eurostat and other internationally recognised sources that summarise the innovation performance of the EU member states founded on four main types of indicators: i) framework conditions such as human

\footnotetext{
${ }^{2}$ Innovation Union Scoreboard (IUS) until 2015.
} 
resources, an attractive research system or an innovationfriendly environment; ii) investments (input) such as finance and support or firm investment; iii) innovation activities (output) such as innovators, linkages or intellectual assets; or iv) impacts (output) such as employment impacts or sales impacts and 10 innovation dimensions that capture 27 different indicators in total (European Commission, 2019b). Alongside the European Innovation Scoreboard, there are innovation indices such as the Massachusetts Innovation Economy index, the Global Innovation Index or the Nordic Innovation Monitor. However, due to the fact that all CEECs (except Albania, which was excluded from this study) are members of the European Union, the European Innovation Scoreboard was considered more suitable than the Global Innovation Index.

In this paper, the author draws upon theories of innovation, institutions, and develops a conceptual model of the relationship between formal and informal institutions and innovation performance (see Figure 1).

Despite the widely held belief that informal and formal institutions matter when it comes to innovation performance, there were no studies that provided evidence of the influence of interplay between formal and informal institutions on the innovation performance of CEECs. Research by Lee \& Law (2017) investigated the impact of formal and informal institutions, albeit on innovation levels not on CEEC innovation performance; while Wang et al. (2019) measured the impact of interplay between formal and informal institutions, albeit on the innovation performance of Chinese firms as opposed to CEECs. Hence, the article focuses on the effect of formal and informal institutional variables on the innovation performance of CEECs.

The data pertaining to the innovation performance of CEECs in this research paper are borrowed from the Summary Innovation Index 2019 (SII), which is a composite indicator summarising the overall performance of each $\mathrm{CEE}$ country's innovation system, built on the composite scores of the EIS for 2018 (European Commission, 2019b). Due to the fact that, according to the EIS methodology report, the results cannot and should not be compared between different EIS reports, the EIS 2019 presenting data for 2018 was chosen for further analysis.

The institutional variables for: i) informal institutions are borrowed from the European Social Survey (ESS): Round 9 (2018) edition 2.0 (except Romania); and ii) formal institutions are borrowed from European Commission (EC) and OECD STIP (science, technology and innovation policy) Compass data for repeated STI policies from 1985 - 2018 and notices of awarded tenders for 2018 from the Tender Electronic Daily (TED) of the supplement to the Official Journal of the European Union.

In the first stage, the following institutional variables were identified for informal institutions: i) trust in legal system (trstlgl); ii) trust in other people (ppltrst); iii) creativity (ipcrtiv); iv) the importance of traditions and customs (imptrad); v) the importance of following the rules (ipfrule); and vi) cooperation (pplhlp); and for formal institutions: vii) theme areas of STIP (STIPT); viii) STIP instrument types (STIPI); and ix) innovative tenders (IT). Due to the fact that less than $0.01 \%$ of CEEC public procurement notices of awarded tenders from TED for 2018 covered innovative evaluation criteria, this variable (IT) was excluded from further analysis.

In the second stage, descriptive statistics were explored for the later investigation of correlation between variables. The statistical results (see Table 1) showed a low level of trust in others and in the legal system, the importance of traditions, customs and rules, as well as a variety of theme areas of STIP among CEECs. These characteristics indicated that the distribution of a number of different formal and informal institutional variables was not symmetrical. The acquired data was statistically evaluated and dependences among the selected data sets were analysed (see Table 2). These relations were statistically significant at the 0.01 level (2tailed), albeit weak (except STIPI).

In the third stage, via the Kolmogorov-Smirnov and Shapiro-Wilk tests, the assumption of normal distribution was rejected.

In the fourth stage, statistical analyses were conducted using IBM SPSS Statistic Program Version 25. The Kruskal-Wallis non-parametric test was employed. The selected test of difference significance allowed the author to verify the null hypothesis:

H0: SIIA = SIIB (there is equality of distribution functions of the level of trust, creativity, cooperation and drive to follow traditions and customs, trust in the legal system and obedience to rules among citizens of CEECs and equality of distribution functions of the variety of policy instruments and theme areas in the compared population of CEECs with high and low levels of innovation performance) against the alternative hypothesis:

$\mathrm{H} 1:$ SIIA $\neq$ SIIB (there is no equality of distribution functions of the level of trust, creativity, cooperation and drive to follow traditions and customs, trust in the legal system and obedience to rules among citizens of CEECs and no equality of distribution functions of the variety of policy instruments and theme areas in the compared population of CEECs with high and low levels of innovation performance)

Where:

SIIA - dependent variable determined by a given factor of formal and informal institutional variables in the compared population of CEECs with a high level of innovation performance;

SIIB - dependent variable determined by a given factor of formal and informal institutional variables in the compared population of CEECs with a low level of innovation performance.

If the significance level was greater than or equal to $\alpha=$ 0.05 , there was no reason to reject H0. However, when the $\alpha$ value was less than 0.05 , the null hypothesis was rejected.

If the statistical value of $\chi^{2}$ exceeds the value read from the chi-square distribution tables for $\alpha=0.05$ and $\mathrm{v}=\mathrm{k}-1$, it can be concluded that the test results confirm the significance of differences between the effects of various levels of trust, creativity, cooperation and drive to follow traditions and customs, trust in the legal system and obedience to rules among citizens of CEECs and the effects of various levels of variety of policy instruments and theme areas on the controlled factor of innovation performance. 


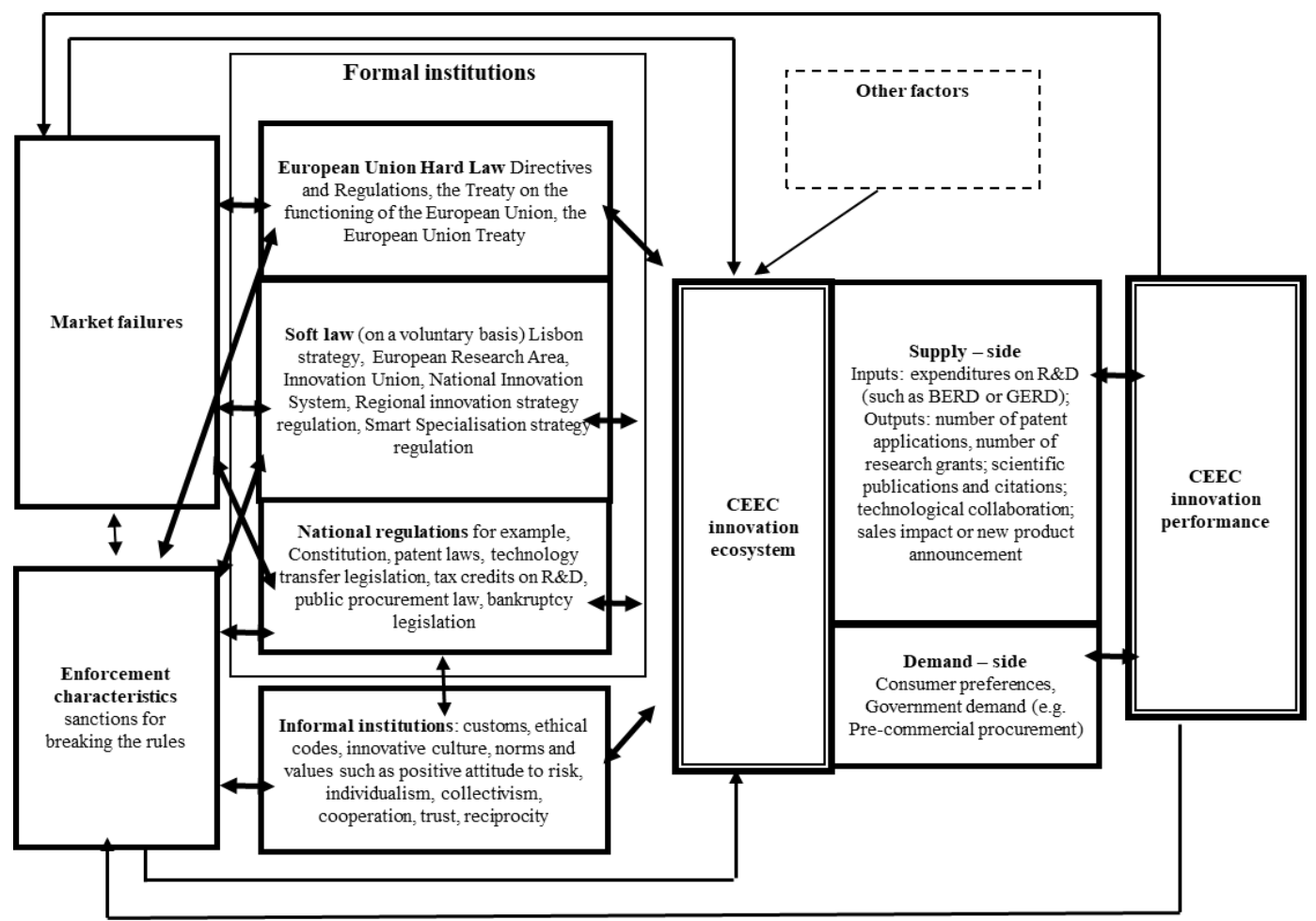

Figure 1. Conceptual model of the relationship between formal and informal institutions and innovation performance Source: Author's own compilation based on the literature on the subject

Descriptive Statistics

\begin{tabular}{|c|c|c|c|c|c|c|c|c|c|}
\hline & \multirow{2}{*}{$\frac{\mathbf{N}}{\text { Statistic }}$} & \multirow{2}{*}{$\begin{array}{r}\text { Minimum } \\
\text { Statistic }\end{array}$} & \multirow{2}{*}{$\frac{\text { Maximum }}{\text { Statistic }}$} & \multirow{2}{*}{$\begin{array}{c}\text { Mean } \\
\text { Statistic }\end{array}$} & \multirow{2}{*}{$\begin{array}{c}\begin{array}{c}\text { Std. } \\
\text { Deviation }\end{array} \\
\text { Statistic }\end{array}$} & \multicolumn{2}{|c|}{ Skewness } & \multicolumn{2}{|c|}{ Kurtosis } \\
\hline & & & & & & Statistic & $\begin{array}{c}\text { Std. } \\
\text { Error }\end{array}$ & Statistic & $\begin{array}{r}\text { Std. } \\
\text { Error }\end{array}$ \\
\hline SII & 18808 & 1 & 11 & 6.05 & 3.40 & -.012 & .018 & -1.415 & .036 \\
\hline ppltrst & 18707 & 0 & 10 & 4.36 & 2.55 & -.057 & .018 & -.778 & .036 \\
\hline pplhlp & 18669 & 0 & 10 & 4.33 & 2.43 & -.012 & .018 & -.640 & .036 \\
\hline trstlgl & 18266 & 0 & 10 & 4.31 & 2.76 & .056 & .018 & -.932 & .036 \\
\hline ipcrtiv & 18061 & 1 & 6 & 2.89 & 1.34 & .496 & .018 & -.537 & .036 \\
\hline ipfrule & 18043 & 1 & 6 & 3.08 & 1.34 & .362 & .018 & -.733 & .036 \\
\hline imptrad & 18808 & 1 & 6 & 2.67 & 1.54 & 1.463 & .018 & 2.746 & .036 \\
\hline Valid N (listwise) & 17268 & & & & & & & & \\
\hline STIPT & 1090 & 1 & 5 & 3.49 & 1.44 & -.070 & .074 & -1.138 & .148 \\
\hline STIPI & 1090 & 1 & 4 & 2.46 & 0.90 & .420 & .074 & .183 & .148 \\
\hline Valid N (listwise) & 1090 & & & & & & & & \\
\hline
\end{tabular}

Source: Author's own compilation

Table 2

Spearman Correlations Coefficient between Independent Variables and Dependent Variable (SII)

\begin{tabular}{|r|r|r|r|r|r|r|r|r|r|}
\hline & & \multicolumn{1}{c|}{ ppltrst } & \multicolumn{1}{c|}{ pplhlp } & \multicolumn{1}{c|}{ trstlgl } & ipcrtiv & ipfrule & imptrad & STIPT & STIPI \\
\hline \multirow{2}{*}{ SII } & $\begin{array}{r}\text { Spearman's rho } \\
\text { Correlation Coefficient }\end{array}$ & $\mathbf{- . 2 1 7} * *$ & $\mathbf{- . 2 3 9} * *$ & $\mathbf{- . 2 8 6} * *$ & $\mathbf{. 0 3 7} * *$ & $\mathbf{- . 1 2 5} * *$ & $\mathbf{- . 1 1 7 * *}$ & $\mathbf{. 0 9 6} * *$ & -.039 \\
\hline & Sig. (2-tailed) & .000 & .000 & .000 & .000 & .000 & .000 & .001 & .201 \\
\hline & $\mathrm{N}$ & 18707 & 18669 & 18266 & 18061 & 18043 & 18808 & 1090 & 1090 \\
\hline
\end{tabular}

Correlation is significant at the 0.01 level (2-tailed).** 


\section{Results}

From both the theoretical and practical points of view, it is very important to answer the question of whether informal or formal institutions of CEECs have a positive, negative or neutral impact on the innovation performance of CEECs economies. Not surprisingly, citizens of the countries with the highest levels of innovation performance among CEECs, such as Estonia, Czechia, Lithuania or Slovenia, have (on average) the highest level of trust in others and/or the legal system (see Table 3). By contrast, countries with the lowest level of innovation performance among CEECs, such as Bulgaria, Romania, Croatia, Poland or Latvia, have (on average) the lowest level of trust in others and/or the legal system. There are, however, two exceptions. One is Slovakia, which has a higher than average level of innovation performance, but a low level of trust in others and/or the legal system. The second is Hungary, which has an average level of innovation performance but a high (on average) level of trust in others and in the legal system.

Similarly, citizens of the countries with the highest innovation performance among CEECs, such as Estonia, Czechia, Lithuania and Slovenia, have (on average) the highest level of cooperation and do not pay much attention (on average) to strictly following traditions and customs (except Slovenia), and rules (except Czechia). By contrast, the countries with the lowest levels of innovation performance among CEECs, such as Bulgaria, Romania, Croatia, Poland or Latvia, have (on average) the lowest level of cooperation (except Latvia) and pay much more attention to following traditions and customs or rules (except Latvia). There are, however, two exceptions. One is Slovakia, which has (on average) a low level of cooperation and pays a great deal of attention to following traditions, customs and rules. The second is Hungary, which has (on average) a high level of cooperation and does not pay much attention to following traditions, customs and rules.

Moreover, citizens of CEECs have a problem with coming up with new ideas or being creative. Only citizens of Czechia, Slovenia and Hungary pay attention to being creative or coming up with new ideas. Surprisingly, citizens of Estonia and Lithuania, on average, believe that it is not important to be creative or come up with new ideas.

As such, the first and third hypotheses were fully validated, but with an opposite (negative) relationship for the following variables: trust in others, trust in the legal system, cooperation and the importance of following rules, traditions and customs. The second hypothesis was not fully validated. The results are presented in Table 4. The null hypothesis must be rejected, because there is no equality of distribution functions in the compared population (except in the case of types of STI policy instruments). The statistical value of $\chi^{2}$ for trust in others, cooperation, creativity, traditions and customs, trust in legal systems, rules or STI policy theme areas exceeds the value read from the chi-square distribution tables for $\alpha=0.05$ and $\mathrm{v}=\mathrm{k}-1$, so it can be concluded that the test results confirm the significance of differences between the effects of various levels of trust in others, cooperation, creativity, traditions and customs, trust in legal systems, rules or STI policy theme areas on the controlled factor of innovation performance of CEECs. There is a significant statistical difference between the level of innovation performance and different levels of trust in others, cooperation, creativity, traditions and customs, trust in legal systems, rules or STI policy theme areas.

Table 3

Differences of Informal Institutions of CEECs (Classified by SII)

\begin{tabular}{|c|c|c|c|c|c|c|c|}
\hline Country & $\begin{array}{c}\text { Summary } \\
\text { Innovation } \\
\text { Index }\end{array}$ & $\begin{array}{c}\text { Trust in other } \\
\text { people (0-You } \\
\text { cannot be too } \\
\text { careful; 10-Most } \\
\text { people can be } \\
\text { trusted) }\end{array}$ & $\begin{array}{c}\text { Trust in the } \\
\text { legal system } \\
\text { (0- No trust } \\
\text { at all; 10- } \\
\text { Complete } \\
\text { trust) }\end{array}$ & $\begin{array}{c}\text { Cooperation (0- } \\
\text { People mostly } \\
\text { look out for } \\
\text { themselves; 10- } \\
\text { People mostly } \\
\text { try to be helpful }\end{array}$ & $\begin{array}{c}\text { Following } \\
\text { traditions and } \\
\text { customs (1- } \\
\text { Very much } \\
\text { like me; 6- Not } \\
\text { like me at al) }\end{array}$ & $\begin{array}{c}\text { Following } \\
\text { rules (1- } \\
\text { Very much } \\
\text { like me; 6- } \\
\text { Not like me } \\
\text { at al) }\end{array}$ & $\begin{array}{c}\text { Be creative } \\
\text { and think new } \\
\text { ideas (1- Very } \\
\text { much like me; } \\
\text { 6- Not like me } \\
\text { at al) }\end{array}$ \\
\hline Estonia & 1 & 5.6 & 5.9 & 5.1 & 3.0 & 3.4 & 3.1 \\
\hline Czechia & 2 & 4.9 & 5.2 & 5.0 & 2.6 & 2.9 & 2.6 \\
\hline Slovenia & 3 & 4.5 & 3.9 & 4.9 & 2.4 & 3.1 & 2.4 \\
\hline Lithuania & 4 & 4.6 & 4.6 & 4.5 & 2.6 & 3.5 & 3.4 \\
\hline Slovakia & 5 & 3.9 & 4.2 & 4.1 & 2.5 & 2.8 & 2.7 \\
\hline Hungary & 6 & 4.7 & 5.5 & 4.7 & 2.8 & 3.5 & 2.6 \\
\hline Latvia & 7 & 4.3 & 4.3 & 5.3 & 2.4 & 3.4 & 2.9 \\
\hline Poland & 8 & 4.0 & 4.3 & 4.0 & 2.3 & 2.8 & 3.1 \\
\hline Croatia & 9 & 4.0 & 2.5 & 3.8 & 2.4 & 3.3 & 2.3 \\
\hline Bulgaria & 10 & 3.5 & 3.0 & 3.6 & 2.3 & 3.0 & 3.6 \\
\hline Romania* & 11 & 3.8 & 3.8 & 3.4 & 2.3 & 2.5 & 2.7 \\
\hline
\end{tabular}

Source: own compilation based on the European Social Survey (ESS): Round 9 (2018) edition 2.0 and Round 4* (2008) edition 4.5 for Romania

Table 4

Test Statistics ${ }^{\mathrm{a}, \mathrm{b}}$

\begin{tabular}{|r|r|r|r|r|r|r|r|r|}
\hline & \multicolumn{1}{|c|}{ ppltrst } & \multicolumn{1}{c|}{ pplhlp } & \multicolumn{1}{c|}{ trstlgl } & ipcrtiv & \multicolumn{1}{c|}{ ipfrule } & imptrad & \multicolumn{1}{c|}{ STIPT } & STIPI \\
\hline Kruskal-Wallis H & 1120.330 & 1344.151 & 2603.182 & 1309.232 & 1158.719 & 522.646 & 41.883 & 10.971 \\
\hline df & 10 & 10 & 10 & 10 & 10 & 10 & 10 & 10 \\
\hline Asymp. Sig. & .000 & .000 & .000 & .000 & .000 & .000 & .000 & .360 \\
\hline
\end{tabular}

a. Kruskal Wallis Test; b. Grouping Variable: Summary Innovation Index; Source: Author's own compilation. 


\section{Discussion}

The study revealed that i) the lower the level of trust in others, trust in the legal system or cooperation among citizens of CEECs, the lower the level of innovation performance of CEEC economies; ii) the greater the variety of policy theme areas and creativity among citizens of CEECs, the higher the level of innovation performance of CEEC economies; and iii) the more important it is to follow traditions and customs or rules as perceived among citizens of CEECs, the lower the level of innovation performance of CEEC economies ${ }^{3}$.

Surprisingly, only the variety of policy theme areas and creativity among citizens of CEECs have a positive impact on the innovation performance of CEECs. These results are in line with those of Phelps (2013) who argued that creativity or insight may support innovation activity, based on tracing the prosperity of nations between 1820 and 1960.

Meanwhile, trust in others, trust in the legal system, cooperation, the importance of following traditions, customs or rules have a negative impact on the innovation performance of CEECs. These results are in line with the OECD (2014), who underlines that if the level of trust in institutions declines, the entire economic system may be weakened (Bonasia et al., 2016), in contrast to Wang et al. (2019), who argue that formal institutions positively affect the relationship between network centrality and innovation performance.

Moreover, Jucevicius et al. (2016) argue that entrepreneurial culture is more critical to innovation performance than the institutional framework and established institutional infrastructure. For this reason, CEECs should strengthen their institutions, as confirmed by this study.

CEECs differ from one another not only due to the differences in formal and informal institutions, but also in terms of social, historical, or political factors (Podkaminer, 2013). However, according to Putnam et al. (1993), these institutional differences between CEECs are mainly connected with differences in informal institutions such as social norms, values, trust or reciprocity, and traditions. This study, in line with Putnam et al. (1993), proved that CEECs such as Bulgaria, Romania, Croatia, or Poland, which have weaker informal institutions, have a lower level of innovation performance, as opposed to Estonia, Czechia or Lithuania, which have much stronger informal institutions and much higher innovation performance.

Scholars emphasise the importance of culture such as traditions, customs, values or norms as a major determinant of innovation performance. However, CEECs, due to their communist past, have a much lower level of trust or cooperation than other EU member states (ESS, 2008, 2018). Unfortunately, institutional quality or trust in institutions is extremely important for high productivity (Kaasa, 2016) and subsequently for high innovation performance, which was proven in this study for informal institutions such as trust in others or trust in the legal system.

The result of the current study, namely that CEECs who place a higher degree of importance on following tradition and customs have a lower level of innovation performance, is in line with Hofstede (1980, 2001), who investigated dimensions of culture such as individualism/collectivism, power distance, femininity/masculinity, uncertainty avoidance, short-term orientation/long-term orientation or indulgence/restraint, and highlighted that they may have a positive or negative impact on management practices, on the innovation performance of firms, and finally on the innovation performance of national economies. CEECs, according to the results of Hofstede's research (1980, 2001), are countries with high power distance (except Estonia or Lithuania), a collectivistic nature (except Hungary, Lithuania, Estonia or Czechia), high levels of uncertainty (except Slovakia, Estonia, Lithuania or Czechia), femininity (except, Hungary, Slovakia or Poland), a long-term orientation and a restrained culture. When viewed together with the results of this study such as the high level of importance placed on following traditions and customs or rules among citizens of CEECs, this may explain why CEECs are not generally perceived as leaders when it comes to innovation.

The results of the current study, namely that CEECs with higher levels of obedience to rules have a lower level of innovation performance, contradict those of Helmke \& Levitsky (2004), who argue that informal institutions may undermine formal ones. However, these results show that low level of trust in the legal system did not undermine a high level of obedience to rules. This study demonstrates that CEECs such as Bulgaria, Romania or Poland, which pay much greater attention to following traditions and customs or rules than do Estonia or Lithuania, have lower levels of innovation performance. Innovation activities need Schumpeterian destruction, creativity, and go beyond schemes set by tradition and customs or rules.

The results of the current study, namely that CEECs with lower levels of trust in the legal system have a lower level of innovation performance, is in line with La Porta et al. (2008) or La Porta et al. (2004), who argue that civil law countries, such as CEECs with German or French legal origins, are associated with greater corruption, a larger unofficial economy or weaker corporate governance systems than common law countries. However, not all scholars agree with the significance of the legal origin of the law.

\section{Conclusions}

This study provides a comprehensive view of the phenomena of interplay between formal and informal institutions and their influence on the innovation performance of CEECs. Knowledge of the influence or lack of influence of interplay between formal and informal institutions on innovation performance is essential for CEEC policymakers. This study highlights that in the case of countries such as Poland with an innovation gap between regions, it is important to identify the major determinants of formal and informal institutions, which have an impact on innovation performance at the national level, but also at the regional level, which requires further investigation.

\footnotetext{
${ }^{3}$ The scale for variables such as following traditions and customs or rules is different than the scale for variables such as trust or cooperation. See Table 3.
} 
This study examined: i) informal institutions such as trust in the legal system, trust in others, creativity, cooperation or the importance of following traditions and customs; ii) formal institutions such as obedience to rules, theme areas of STIP, STIP instrument types or innovative tenders; and iii) interplay between the level of trust in the legal system and obedience to rules.

The results suggest that i) the lower the level of trust in others, trust in the legal system or cooperation among citizens of CEECs, the lower the level of innovation performance of CEEC economies; ii) the greater the variety of policy theme areas and/or creativity among citizens of CEECs, the higher the level of innovation performance of CEEC economies; and iii) the more important it is to follow traditions and customs or rules as perceived by citizens of CEECs, the lower the level of innovation performance of CEEC economies.

The authors' contribution to filling the knowledge gap in institutional and innovation theory and research is done by i) creating a conceptual model which combines the relationship between formal and informal institutions of CEECs and innovation performance; ii) showing that only the variety of policy theme areas and creativity among citizens of CEECs have a positive impact on the level of innovation performance of CEEC economies. Meanwhile, trust in others, trust in the legal system, the importance of following traditions and customs or cooperation among citizens of CEECs, as well as interplay between informal institutions such as trust in the legal system and formal institutions such as obedience to rules among citizens of CEECs have a negative impact on the level of innovation performance of CEEC economies, due to weak informal institutions in the most of CEECs; and iii) revealing that CEECs such as Bulgaria, Romania or Poland, which have lower levels of cooperation, trust in the legal system or trust in others and pay much more attention to following traditions and customs or rules than Estonia, Czechia or Lithuania, have lower levels of innovation performance.

According to the results of research by Hofstede (1980, 2001), CEECs are countries with high power distance (except Estonia or Lithuania), a collectivistic nature (except Hungary, Lithuania, Estonia or Czechia), high levels of uncertainty (except Slovakia, Estonia, Lithuania or Czechia), femininity (except Hungary, Slovakia or Poland), a long-term orientation and a restrained culture. In combination with the results of this study, namely that high levels of importance placed on following traditions and customs or rules among citizens of CEECs influence the level of CEEC innovation performance, may explain why most CEECs are not perceived as being among the leaders in innovation.

\section{Limitation of the Study}

Due to limitations in the currently available data, the paper did not analyse a wider range of variables within formal institutions.

\section{References}

Acs, Z. J., \& Varga A. (2002). Geography, Endogenous Growth and Innovation. International Regional Science Review, 25(1), 132-148. https://doi.org/10.1177/016001702762039484

Adam, F. (2014). Innovation Union Scoreboard: Central Monitoring System for the EU. In: Measuring National Innovation Performance. SpringerBriefs in Economics (pp. 15-19). Berlin, Heidelberg: Springer. https://doi.org/10.1007/978-3642-39464-5_4

Ashford, N. A. (2000). An Innovation-Based Strategy for a Sustainable Environment. In: J. Hemmelskamp, K. Rennings \& F. Leone (Eds.). Innovation-oriented Environmental Regulation. Theoretical Approaches and Empirical Analysis (pp. 67-109). Mannheim: ZEW Economic Studies 10. https://doi.org/10.1007/978-3-662-12069-9 5

Autio, E., \& Acs, Z. (2010). Intellectual property protection and the formation of entrepreneurial growth aspiration. Strategic Entrepreneurship Journal, 4 (3), 234-251. https://doi.org/10.1002/sej.93

Belas, J., Rahman, R., Rahman, M. T., \& Schonfeld, J. (2017). Financial Constraints on Innovative SMEs: Empirical Evidence from the Visegrad Countries. Inzinerine Ekonomika-Engineering Economics, 28(5), 552-563. https://doi.org/10.5755/j01.ee.28.5.18204

Berend, I. T. (2009). From the Soviet Bloc to the European Union. The Economic and Social Transformation of Central and Eastern Europe since 1973. Cambridge: Cambridge University Press. https://doi.org/10.1017/CBO97 $\underline{80511806995}$

Bergiel, E. B., Bergiel, B. J., \& Upson, J. W. (2012). Revisiting Hofstede's Dimensions: Examining the Cultural Convergence of the United States and Japan. American Journal of Management, 12(1), 69-79.

Birchall, D., Chanaron, J. J., Tovstiga, G., \& Hillenbrand, C. (2011). Innovation performance measurement: current practices, issues and management challenges. International Journal of Technology Management, 56(1), 1-20. https://doi.org/10.1504/IJTM.2011.042492

Bonasia, M., Canale, R. R., Liotti, G., \& Spagnolo N. (2016). Trust in Institutions and Economic Indicators in the Eurozone: the Role of the Crisis. Inzinerine Ekonomika-Engineering Economics, 27(1), 4-12. https://doi.org/10.57 $\underline{\text { 55/j01.ee.27.1.12581 }}$

Chen, M. H., Chang, Y. C., \& Hung, S. C. (2008). Social capital and creativity in R\&D project teams. R\&D Management, 38(1), 21-34. https://doi.org/10.1111/j.1467-9310.2007.00494.x 
Cheng, L., Nsiah, T. K., Sun, K., \& Zhuang, Z. (2020). Institutional environment, technical executive power and agricultural enterprise innovation performance. Cogent Business \& Management, 7(1), 1-20. https://doi.org/10.1080/ $\underline{23311975.2020 .1743619}$

Chiu, I. H. Y. (2017). A new era in fintech payment innovations? A perspective from the institutions and regulation of payment systems. Law, Innovation and Technology, 9(2), 190-234. https://doi.org/10.1080/17579961.2017.1377912

Cooke, P., Gomez Uranga, M., \& Etxeberria, G. (1997). Regional innovation systems: institutional and organisational dimensions. Research Policy, 26(4/5), 475-491. https://doi.org/10.1016/S0048-7333(97)00025-5

Czudec, A., Kata, R., \& Wosiek, M. (2019). Reducing the development gaps between regions in Poland with the use of European Union funds. Technological and Economic Development of Economy, 25(3), 447-471. https://doi.org/10.3 846/tede.2019.9483

Denning, P. J. \& Dunham, R. (2010). The Innovator's Way: Essential Practices for Successful Innovation. Cambridge, Massachusetts, London: The MIT Press.

Djankov, S., La Porta, R., Lopez-De-Silva, F., \& Shleifer, A. (2002). The regulation of entry. Quarterly Journal of Economics, CXVII(1), 1-37. https://doi.org/10.1162/003355302753399436

Dukic, S., Stankovic, L., \& Lepojevic, V. (2015). Improvement of Innovation Capacity of SMEs in Republic of Serbia by Connecting with Key Stakeholders. Inzinerine Ekonomika-Engineering Economics, 26(4), 431-441. https://doi.org/10.5755/j01.ee.26.4.8489

Edquist, C. (Ed.) (2005). Systems of Innovations.London and New York: Routledge.

Edquist, C., Zabala, J. (2012). Knowledge-intensive Entrepreneurship, National Systems of Innovation and European Varieties of Capitalism: A Conceptual Framework. AEGIS Technical report.

Edquitst, C., \& Johnson, B. (2005). Institutions and Organization in System of Innovation. In: C. Edquist (Ed.), Systems of Innovations (pp. 36-63).London and New York: Routledge.

European Commission (2014). State of the Innovation Union. Taking stock 2010-2014. Available from internet: http://ec.europa.eu/research/innovation-union/pdf/state-of-theunion/2013/state_of_the_innovation_union_report_2013.pdf

European Commission (2016). Better regulations for innovation-driven investment at EU level. Commission Staff Working Document. Available from internet: https://op.europa.eu/pl/publication-detail/-/publication/404b82db-d08b-11e5a4b5-01aa75ed71a1/

European Commission (2019a). European innovation scoreboard 2019. Database. Available from internet: https://ec.europa.eu/docsroom/documents/36062

European Commission (2019b). European innovation scoreboard 2019. Methodology Report. Available from internet: https://ec.europa.eu/docsroom/documents/36062

European Commission and OECD (2020). STIP Compass policy analysis. Available from internet: https://stip.oecd. org/stip.html

Ghazinoory, S., Riahi, P., Azar, A., \& Miremadi, T. (2014). Measuring innovation performance of developing regions: learning and catch-up in provinces of Iran. Technological and Economic Development of Economy, 20(3), $507-533$. https://doi.org/10.3846/20294913.2014.881433

Godlewska, M. (2019). Do interactions between formal and informal institutions matter for productive entrepreneurship? Ekonomia i Prawo. Economics and Law, 18(1), 17-28. https://doi.org/10.12775/EiP.2019.002

Granieri, M. \& Renda, A. (2012). Innovation Law and Policy in the European Union. Towards Horizon 2020. Springer. eBook. https://doi.org/10.1007/978-88-470-1917-1

Hagedoorn, J., \& Cloodt, M. (2003). Measuring Innovative Performance: Is There an Advantage in Using Multiple Indicators?. Research Policy, 32(8), 1365-1379. https://doi.org/10.1016/S0048-7333(02)00137-3

Herbig, P., \& Dunphy, S. (1998). Culture and innovation. Cross Cultural Management, 5(4), 13-21. https://doi.org/10.11 $\underline{08 / 13527609810796844}$

Hofstede, G. (1980). Culture's Consequences: International Differences in Work-Related Values. London: Sage Publications.

Hofstede, G. (2001). Culture's consequences. Thousand Oaks: Sage Publications.

Hollanders, H., \& van Cruysen, A. (2008). Rethinking the European Innovation Scoreboard: A New Methodology for 2008-2010. Maastricht University. Available from internet: https://eu.eustat.eus/elementos/ele0006100/ Methodology_Report_EIS_2008-2010/inf0006199_e.pdf 
Hsu, Ch. W., Lien, Y. Ch., \& Chen, H. (2015). R\&D internationalisation and innovation performance. International Business Review, 24(2), 187-195. https://doi.org/10.1016/j.ibusrev.2014.07.007

Jorde, T. M., \& Teece, D. J. (1990). Innovation and Cooperation: Implications for Competition and Antitrust. Journal of Economics Perspectives, 4(3), 75-96. https://doi.org/10.1257/jep.4.3.75

Jucevicius, G., Juceviciene, R., Gaidelys, V., \& Kalman A. (2016). The Emerging Innovation Ecosystems and "Valley of Death": Towards the Combination of Entrepreneurial and Institutional Approaches. Inzinerine EkonomikaEngineering Economics, 27(4), 430-438. https://doi.org/10.5755/j01.ee.27.4.14403

Kaasa, A. (2016). Social Capital, Institutional Quality and Productivity: Evidence from European Regions. Economics and Sociology, 9(4), 11-26. https://doi.org/10.14254/2071-789X.2016/9-4/1

Kraftova, I., \& Kraft, J. (2018). The Relationship between Pro-Innovation Factors and the Performance of the European Union Member States and their Regions. Inzinerine Ekonomika-Engineering Economics, 29(4), 424-433. https://doi.org/10.5755/j01.ee.29.4.19703

La Porta, R., Lopez-de-Silanes, F., \& Shleifer A. (2008). The economic consequences of legal origins. Journal of Economic Literature, 46(2), 285-332. https://doi.org/10.1257/jel.46.2.285

La Porta, R., Lopez-de-Silanes, F., Pop-Eleches, C., \& Shleifer A. (2004). Judicial checks and balances. Journal of Political Economy, 112(2), 445-470. https://doi.org/10.1086/381480

Lee, W. C., \& Law, S. H. (2017). Roles of Formal Institutions and Social Capital in Innovation Activities: A Cross-Country Analysis. Global Economic Review, 46(3), 203-231. https://doi.org/10.1080/1226508X.2017.1292859

Lundvall, B. A. (1992). National Systems of Innovation: Towards a Theory of Innovation and Interactive Learning. London: Pinter.

Lundvall, B. A. (2007). National Innovation Systems-Analytical Concept and Development Tool. Industry and Innovation, 14(1), 95-119. https://doi.org/10.1080/13662710601130863

Mir-Babayev, R., Gulaliyev, M., Shikhaliyeva, S., Azizova, R., \& Ok, N. (2017). The Impact of Cultural Diversity on Innovation Performance: Evidence from Construction Industry of Azerbaijan. Economics and Sociology, 10(1), 7893. https://doi.org/10.14254/2071-789X.2017/10-1/6

Mokyr, J. (1991). The Lever of Riches: Technological Creativity and Economic Progress. London: Oxford University Press.

North, D.C. (1990). Institutions, Institutional Change, and Economic Performance. New York, NY: Cambridge University Press. https://doi.org/10.1017/CBO9780511808678

OECD Oslo Manual (2005). Guidelines for collecting and interpreting innovation data. Available from internet: https://www.oecd-ilibrary.org/docserver/9789264013100en.pdf?expires=1592403101\&id=id\&accname=guest\&checksum=6A8FA2EF41FBCE9379EE355F331F2FC5

Pejovich, S. (1999). The Effects of the Interaction of Formal and Informal Institutions on Social Stability and Economic Development. Journal of Markets \& Morality, 2(2), 164-181.

Pelkmans, J., \& Renda, A. (2014). How Can EU Legislation Enable and / or Disable Innovation. European Commission. Avaliable from internet: https://ec.europa.eu/futurium/en/system/files/ged/39-how_can_eu_legislation_enable_andor_disable_innovation.pdf

Phelps, E.S. (2013). Mass flourishing: how grassroots innovation created jobs, challenge, and change. Princeton: Princeton University Press. https://doi.org/10.1515/9781400848294

Podkaminer, L. (2013). Development patterns of Central and East European countries (in the course of transition and following EU accession). Research Report No. 388, The Vienna Institute for International Economic Studies. Avaliable from internet: https://wiiw.ac.at/development-patterns-of-central-and-east-european-countries-in-thecourse-of-transition-and-following-eu-accession-p-2985.html

Prokop, V., \& Stejskal, J. (2017). Different Approaches to Managing Innovation Activities: An Analysis of Strong, Moderate, and Modest Innovators. Inzinerine Ekonomika-Engineering Economics, 28(1), 47-55. https://doi.org/10. 5755/j01.ee.28.1.16111

Putnam, R. (1993). Making Democracy Work. Princeton NJ: Princeton University Press.

Romer, P. (1990). Endogenous Technological Change. Journal of Political Economy, 98(5), 71-102. https://doi.org/10.10 $\underline{86 / 261725}$

Qu, Y., Qu, T., \& Wu, Y. (2017). The role of regional formal institutions and foreign direct investment in innovation in Chinese enterprises. Asia Pacific Business Review, 23(1), 27-43. https://doi.org/10.1080/13602381.2015.1094293 
Sekliuckiene, J., Sedziniauskiene, R., \& Viburys, V. (2016). Adoption of Open Innovation in the Internationalisation of Knowledge Intensive Firms. Inzinerine Ekonomika-Engineering Economics, 27(5), 607-617. https://doi.org/10.57 55/j01.ee.27.5.15371

Shane, S. (1993). Cultural influences on national rates on innovation. Journal of Business Venturing, 8(1), 59-73. https://doi.org/10.1016/0883-9026(93)90011-S

Shahzad, F., Xiu, G. Y., \& Shahbaz, M. (2017). Organisational culture and innovation performance in Pakistan's software industry, Technology in Society, 51, 66-73. https://doi.org/10.1016/j.techsoc.2017.08.002

Sitanyi, L. (2010). The innovation position of four neighbouring countries and Hungary Based on the "European Innovation Scoreboard". Regional and Business Studies, 2(1), 1-21.

Smith, K. (2005). Measuring innovation.In J. M. D. C Fagenberg. \& R. R. Nelson(Eds.). The Oxford Handbook of Innovation (pp. 148-179). Oxford: Oxford University Press. https://doi.org/10.1093/oxfordhb/978019928 $\underline{6805.003 .0006}$

Soares, A., Farhangmehr, M., \& Shoham, A. (2007). Hofstede's dimensions of culture in international marketing studies. Journal of Business Research, 60(3), 277-284. https://doi.org/10.1016/j.jbusres.2006.10.018

Sternberg, R., \& Arndt, O. (2001). The Firm or the Region: What Determines the Innovation Behaviour of European Firms?. Economic Geography, 77(4), 364-382. https://doi.org/10.2307/3594106

Tabellini, G. (2010). Culture and Institutions: Economic Development in the Regions of Europe. Journal of the European Economic Association, 8(4), 677-716. https://doi.org/10.1111/j.1542-4774.2010.tb00537.x

Tassey, G. (2007). Tax incentives for innovation: time to restructure the R\&D tax credit. Journal of Technology Transfer, 32, 605-615. https://doi.org/10.1007/s10961-007-9045-Z

Tidd, J. (2006). A Review of Innovation Models. London: Imperial College London.

Wang, H., Zhao, Y., Dang, B., Han, P., \& Shi, X. (2019). Network centrality and innovation performance: the role of formal and informal institutions in emerging economies. Journal of Business \& Industrial Marketing, 34(6), 13881400. https://doi.org/10.1108/JBIM-09-2017-0228

Westwood, R., \& Low, D. R. (2003). The multicultural muse: culture, creativity and innovation. International Journal of Cross Cultural Management, 3(2), 235-259. https://doi.org/10.1177/14705958030032006

Williams, L., \& McGuire, S. (2010). Economic creativity and innovation implementation: the entrepreneurial drivers of growth? Evidence from 63 countries. Small Business Economics, 34(4), 391-412. https://doi.org/10.1007/s11187$\underline{008-9145-7}$

Zdrazil, P., Kraftova, I., \& Mateja, Z. (2016). Reflection of Industrial Structure in Innovative Capability. Inzinerine Ekonomika-Engineering Economics, 27(3), 304-315. https://doi.org/10.5755/j01.ee.27.3.13634

Zhao, A. ., Sun, Z. ., Guan, H. ., \& Jia, J. (2020). Research on the evolution of innovation behavior of new generation entrepreneurs in different scenarios. Technological and Economic Development of Economy, 26(5), 1098-1124. https://doi.org/10.3846/tede.2020.12373

\section{Authors' biographies}

Malgorzata Godlewska is $\mathrm{PhD}$, Assistant Professor in Department of Administrative and Corporate Law in Collegium of Business Administration at SGH Warsaw School of Economics in Poland. Researcher in law \& economics. ORCID iD 0000-0001-7413-0674. The recent publications:

Godlewska, M., \& Morawska, S. (2020). Development of local and regional entrepreneurship-which institutions matter? Evidence from Poland. Economic Research-Ekonomska Istrazivanja, 33(1), 1017-1035. doi:10.1080/1331677X.2018.1553680 OR

Godlewska, M. \& Pilewicz, T. (2020). Entrepreneurial activities of local governments in their investment attractiveness context - evidence from Poland. Local Government Studies, doi: 10.1080/03003930.2020.1842736

The article has been reviewed.

Received in July 2020; accepted in February 2021.

This article is an Open Access article distributed under the terms and conditions of the Creative Commons Attribution 4.0 (CC BY 4.0) License (http://creativecommons.org/licenses/by/4.0/). 